J. Amer. Soc. Hort. Sci. 118(3):339-342. 1993.

\title{
Nitrogen Supply during Greenhouse Transplant Production Affects Subsequent Tomato Root Growth in the Field
}

\author{
A. Liptay and S. Nicholls \\ Agriculture Canada, Research Station, Harrow, Ont., NOR 1G0, Canada \\ Additional index words. field establishment, hardening, stress, Lycopersicon esculentum
}

\begin{abstract}
Tomato transplant (Lycopersicon esculentum Mill.) root growth in the field was directly related to $\mathrm{N}$ level supplied to the transplants as seedlings in the greenhouse. Root growth in the field increased exponentially when $\mathrm{N}$ was applied at 50 to $350 \mathrm{mg} \cdot$ liter $^{-1}$. Transplant growth in multicelled trays increased in a sigmoidal fashion with $\mathbf{N}$, up to $200 \mathrm{mg}$-liter'. The optimal $\mathrm{N}$ range for maximum survival, growth, and early yield in the field was from 100 to $200 \mathrm{mg}$-liter'. Strength of the seedling stem increased with $\mathrm{N}$ level curvilinearly. Seedling survival in the field was highly correlated with seedling stem strength.
\end{abstract}

Nitrogen supplied to tomato seedlings affects growth in the greenhouse and has a carryover effect in the field after transplanting (Garton and Widders, 1990; Melton and Dufault, 1991a, 1991b; Weston and Zandstra, 1989; Widders, 1989). Increasing the amount of $\mathrm{N}$ fed to the seedlings in the greenhouse increased the amount of early shoot growth in the field and accelerated maturity for harvest. Elevating the level of $\mathrm{N}$ fed to tomato seedlings from 25 to 75 or $225 \mathrm{mg} \cdot$ liter $^{-1}$ enhanced growth, however, further increases to $300 \mathrm{mg} \cdot \operatorname{liter}^{-1}$ gave no additional benefit (Melton and Dufault, 1991a, 1991b). The effect of N supply during transplant production was carried over into the field in several studies (Garton and Widders, 1990; Weston and Zandstra, 1989; Widders, 1989).

The objectives of the current study were to 1) correlate tomato seedling growth in the field with $\mathrm{N}$ feeding in the greenhouse, 2) examine growth variables affected by varying $\mathrm{N}$ concentrations, and 3 ) assess the effect of varying $\mathrm{N}$ concentrations on transplant survival in the field. The latter was a particularly important consideration for southwestern Ontario because sandblasting damage often occurs on sandy soils after high wind episodes requiring replanting.

\section{Materials and Methods}

Processing tomato (Lycopersicon esculentum Mill.) cultivar TH-318 seeds were sown into ASB (ASB-Greenworld, N.J.) peatbased growing medium in "288" Sutton trays (cell density of 1830/ $\mathrm{m}^{2}$ and cell volume of $4.5 \mathrm{~cm}^{3}$ ). The seeded trays were placed in a germination chamber at $25 \mathrm{C}$ for $60 \mathrm{~h}$ until the first seedlings emerged and were then transferred to a greenhouse $(26 \pm 2 \mathrm{C}$, day $16 \mathrm{~h}$ and $18 \pm 2 \mathrm{C}$, night $8 \mathrm{~h}$ ). Light was supplemented with high pressure sodium lamps with an intensity of $40 \mathrm{~W} \cdot \mathrm{m}^{2}$ at the canopy level. Beginning on the 10th day after sowing, the following mineral solutions $\left(\mathrm{mg} \cdot \mathrm{liter}^{-1}\right)$ having common $25 \mathrm{P}-250 \mathrm{~K}-100 \mathrm{Ca}-$ $40 \mathrm{Mg}$ levels but with varying $\mathrm{N}$, i.e., $0,50,100,200$, or 350 , were supplied five times per week at $400 \mathrm{ml}$ per tray; tap water was used as required at other times. Treatments were replicated four times and repeated three times, i.e., in Spring 1988, Autumn 1988, and Spring 1989.

Received for publication 24 Dec. 1991. Accepted for publication 19 Oct. 1992. The cost of publishing this paper was defrayed in part by the payment of page charges. Under postal regulations, this paper therefore must be hereby marked advertisement solely to indicate this fact.
Structural strength of the seedling stems was determined at transplanting time with an Ottawa Texture Measuring System (Engineering Research Service, Agriculture Canada, Ottawa, Ont.) using a Warner Bratzler shear cell. Strength was determined using 10 stem sections from between the first and second leaf nodes. Nitrogen analysis was done on a Traacs 800 Autoanalyzer (Bran \& Lubbe, Buffalo Grove, Ill.) on dried composite samples of four seedlings for each treatment, i.e., $0,50,100,150,200,250$, and 300 $\mathrm{N}$ mg.liter ${ }^{-1}$.

Seedlings, 5 to 6 weeks old, from the 50,100, 200, and 350 $\mathrm{mg} \cdot \mathrm{liter}^{-1} \mathrm{~N}$ levels were transplanted into fields of Grandby Sandy Loam or Fox Sandy Loam soils on4 May 1988 and on 8 May 1989. One hundred milliliters of a 20-20-20 commercial formulation of soluble fertilizer was applied in the furrow to each plant at transplanting. The fertility of the soil was assayed and considered to be high for $\mathrm{P}$ and $\mathrm{K}$ levels. The field was fertilized with $10 \mathrm{~kg}$ $\mathrm{N}, 40 \mathrm{~kg} \mathrm{P}$, and $40 \mathrm{~kg} \mathrm{~K} / \mathrm{ha}$; the fertilizer was broadcast preplant into the soil. The plants were spaced $1.5 \mathrm{~m}$ between rows and 0.3 $\mathrm{m}$ in the row; they were sidedressed with $100 \mathrm{~kg} \mathrm{~N} / \mathrm{ha} 5$ weeks after transplanting. The herbicides treflan and metribuzin, at the recommended rates, were used for weed control.

The field experiment was a randomized block design with four replicates. Statistical analyses included ANOVA, LSD, and/or nonlinear growth curve analysis.

Field survival, i.e., whether transplants were dead or alive, was assessed 30 days after transplanting in 1988 and 27 days thereafter in 1989. Seedling root length was measured, roots were counted, and dry weights were taken of the new-growth, i.e., the lightcolored roots growing beyond the darker-colored ones of the root ball.

Tomatoes were harvested once per week for 4 weeks from both soil types in 1988 and only from plants that had survival "guard" plants on either side; but, tomatoes were not harvested in 1989 because a $200 \mathrm{~mm}$ rainfall destroyed the crop on 20 July of that year.

\section{Results}

Tomato seedling heights (Fig. 1A) and shoot $\mathrm{N}$ concentration (Fig. 1B) in the greenhouse increased exponentially to a maximum at $\approx 150 \mathrm{mg} \cdot$ liter $^{-1}$. Similar patterns were observed for fresh and dry weights (not reported). Seedling stem diameters increased with $\mathrm{N}$ concentration (Fig. 2).

The dry weight of new root growth in the field increased with 


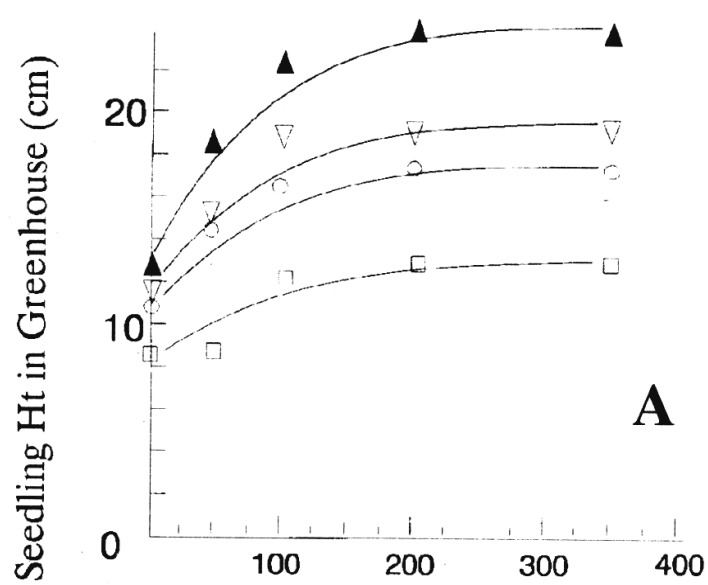

Nitrogen Fed to Seedlings in Greenhouse (mg/l)

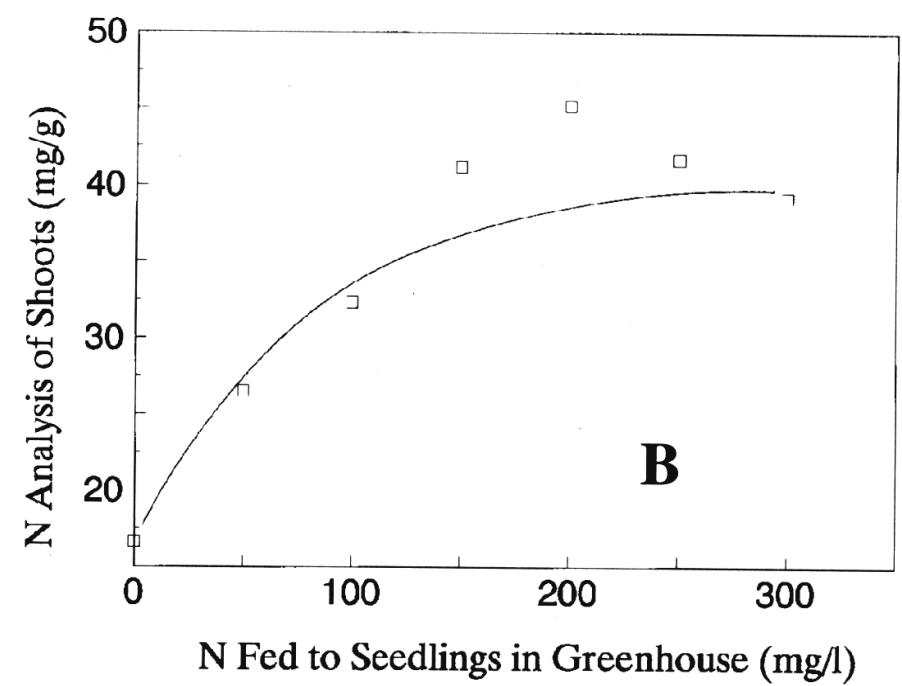

Fig. 1. (A) Relationship between tomato seedling height in the greenhouse and $\mathrm{N}$ levels received in feeding solution, i.e., 0, 50, 100, 200, or $350 \mathrm{mg} \cdot \mathrm{liter}^{-1}$. The seedling heights for the N concentration curves were taken on days $23(\square), 31(\mathrm{~m})$, $38(\nabla)$, and $49(\Delta)$ after sowing. The equations for the general logistic curves were day $23, \mathrm{Y}=-241.8+266 /(1+\operatorname{EXP}(-0.028(\mathrm{X}+85.2)))$; day $31, \mathrm{Y}=9.83+9.12 /$ $(1+\operatorname{EXP}(-0.095(\mathrm{X}-45.3)))$; day $38, \mathrm{Y}=-227.6+244.9 /(1+\operatorname{EXP}(-0.033(\mathrm{X}+$ $87)))$; day $49, \mathrm{Y}=8.8+4.48 /(1+\operatorname{EXP}(-0.085(\mathrm{X}-84.5)))$. The residual mean squares for the logarithmic curves were $0.24,0.2,0.005$, and 0.29 , respectively. (B) Nitrogen content of seedlings vs. level of $\mathrm{N}$ received by seedlings, i.e., 0,50 , $100,150,200,250$, or $300 \mathrm{mg} \cdot$ liter $^{-1}$. Seedlings were 4 weeks of age at the time of analysis. The residual mean square was 11.42 for the exponential curve, $\mathrm{Y}=$ $\mathrm{A}+\mathrm{B} \cdot \mathrm{R} \cdot \mathrm{X}, \mathrm{R}=\mathrm{EXP}(-\mathrm{K})$ where $\mathrm{A}=43.5, \mathrm{~B}=-28.6, \mathrm{R}=0.99$, and $\mathrm{K}=0.01$.

time and with increasing $\mathrm{N}$ concentration supplied during transplant production in the greenhouse (Fig. 3A). Moreover, there was $40 \%$ more root growth in the field than in the greenhouse at 350 vs. $200 \mathrm{mg} \cdot \mathrm{liter}^{-1} \mathrm{~N}$. The new root growth was a result of both an increased length of roots and an increase in the number of laterals (measured and counted manually, data not shown). The root system was larger with higher $\mathrm{N}$ concentrations when evaluated 23 days after field setting (Fig. 3B).

Survival in the field after normal windy sandblasting conditions of the spring (see Fig. 4) was the lowest for $350 \mathrm{mg}$ N/liter; means for 50, 100, and $200 \mathrm{mg} \mathrm{N} /$ liter were similar ( $t$ test, $P \leq 0.05$ ).

The structural strength (Fig. 5) of the stems changed with the various $\mathrm{N}$ levels in a manner similar to that of the seedling survival after sandblasting conditions. Stem strength (Y) and survival (X)
$(\mathrm{Y}=-42.8+10.5 \mathrm{X})$ were highly correlated (Pearson, $r=0.95)$.

The differences in the greenhouse $\mathrm{N}$ level treatments, on a per plant basis, were evident up to the early harvest. Early yields averaged from both soil types in 1988 were lowest at $50 \mathrm{mg} \mathrm{N} / \mathrm{liter}$ (Fig. 6). The analysis of variance (ANOVA) with three treatment degrees of freedom and 12 error degrees of freedom indicated mean squares of 40.37 and 7.69 , respectively. The LSD, $P=0.05$, was 4.1 tomatoes per plant; the 50 and $100 \mathrm{mg} \cdot \mathrm{liter}^{-1}$ applications led to lower early yields than did the higher $\mathrm{N}$ ones. There were no differences in the total yields among the $\mathrm{N}$ feeding levels.

\section{Discussion}

Feeding tomato seedlings high $\mathrm{N}$ levels in the greenhouse enhanced their capacity for root growth in the field (Fig. 3A). Higher $\mathrm{N}$ levels in the seedlings (Fig. $1 \mathrm{~B}$ ) immediately after field planting may mean that stored $\mathrm{N}$ was more readily used for growth than soil N. This availability may be an important factor in rapid seedling establishment even though Bums (1980) reported that most crops grow normally with $>15 \%$ of their roots exposed to N. How efficiently nutrients are taken up from the soil from newly placed root systems such as those of transplants is unknown. More work is needed to test the hypothesis that $\mathrm{N}$ assimilated before transplanting may have enhanced the rate of seedling establishment.

Although maximum root growth in the field occurred with the $350 \mathrm{mg} \cdot$ liter $^{-1} \mathrm{~N}$ regime during greenhouse production (Fig. 3A), this rate cannot be recommended because of the lack of hardening at this $\mathrm{N}$ level, and the susceptibility of these seedlings to sandblasting damage (Fig. 4). The good correlation between structural strength of the seedlings and survivability (Figs. 4 and 5) suggests that stem structural strength is an important characteristic contributing to the hardiness of tomato seedlings. This hardiness characteristic is especially important to ensure field survival of transplants on sandy soils that are prone to sandblasting.

In conclusion, we recommend that tomato seedlings grown in the greenhouse for transplanting outdoors be fed from 100 to 200 $\mathrm{mg} \mathrm{N} /$ liter. This level of $\mathrm{N}$ results in somewhat less rapid root and shoot growth than at 350; however, overall field survival is

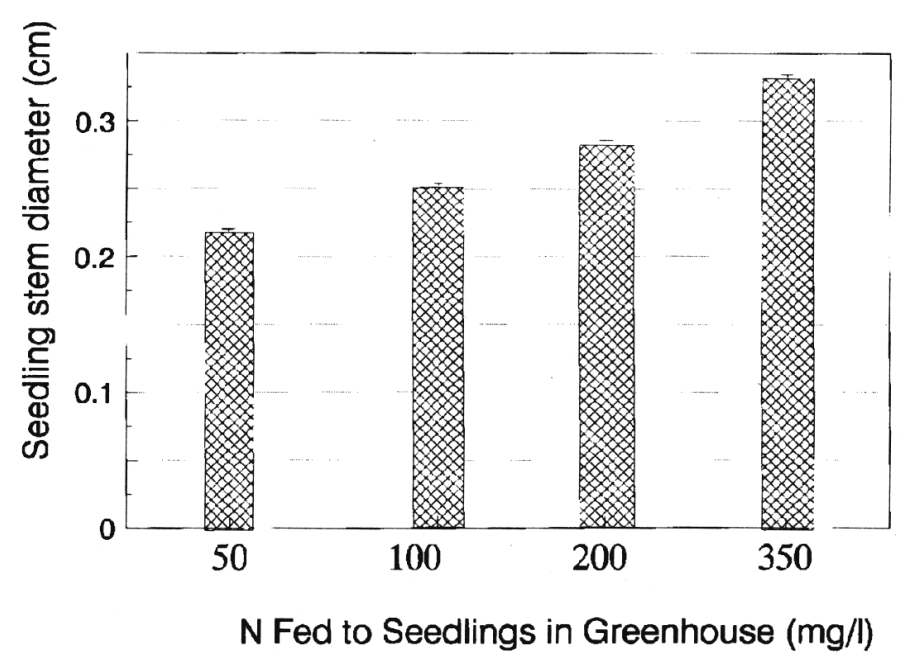

Fig. 2. Relationship between tomato seedling stem diameter on day 28 after germination in the greenhouse and $\mathrm{N}$ levels received in feeding solution, i.e., 0 , $50,100,200$, or $350 \mathrm{mg} \cdot \mathrm{liter}^{-1}$. The LSD test indicated that the stem diameter for the $50 \mathrm{mg} \cdot$ liter $^{-1} \mathrm{~N}$ feeding did not differ from the $100 \mathrm{mg} \cdot$ liter $^{-1}$ feeding regime at $\mathrm{P} \leq 0.05$, but differed from the other concentrations; there were no other differences. 

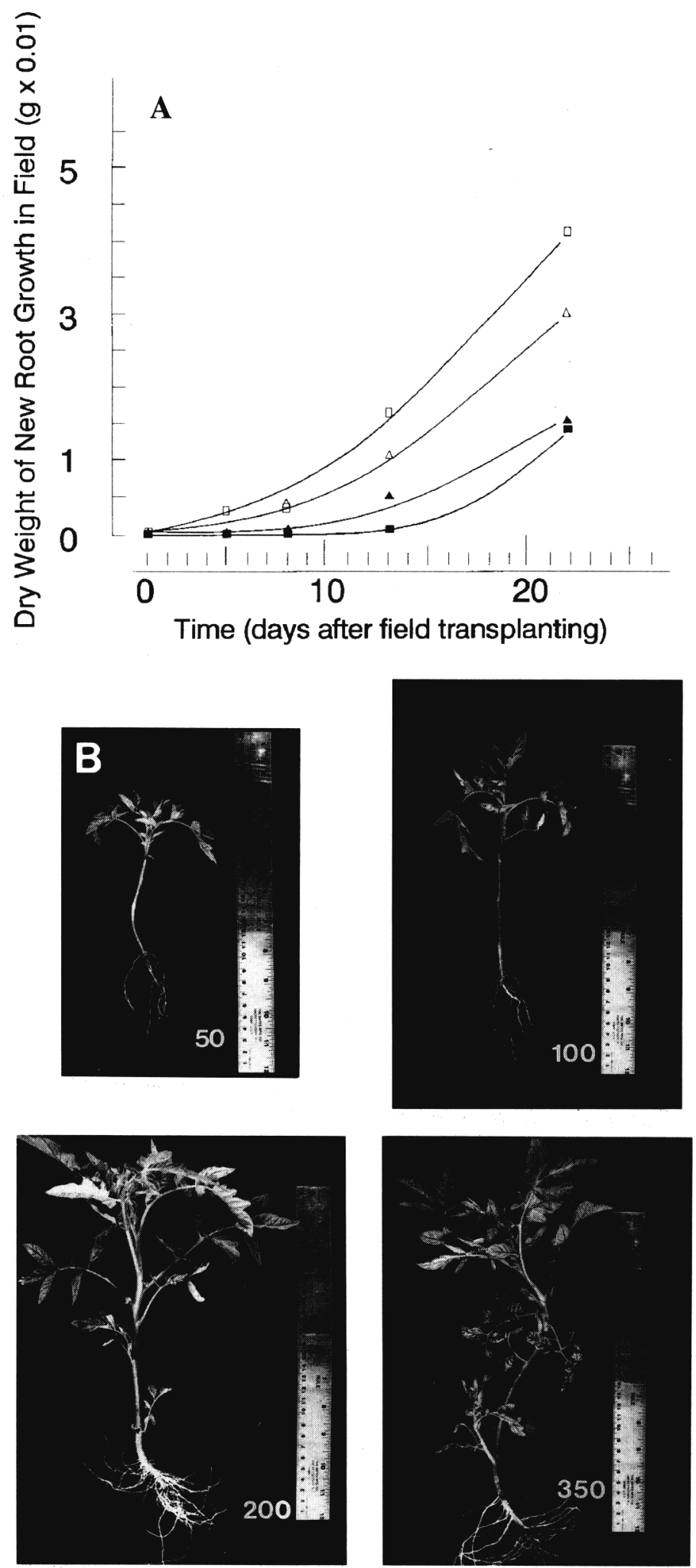

Fig. 3. (A) Dry weights of new roots formed per seedling in the field for various $\mathbf{N}$ levels in the greenhouse $\left(50(\square), 100(\Delta), 200(\Delta)\right.$, or $350(\square) \mathrm{mg} \cdot$ liter $^{-1)}$. Roots from two seedlings from each of four replicates were measured. The equations of the curves for the N levels were $50 \mathrm{mg} \cdot \mathrm{lite}^{-1}, \mathrm{Y}=0.024+1.43 /(1+\operatorname{EXP}(-3.84(\mathrm{X}$ $-13.4))) ; 100 \mathrm{mg} \cdot \mathrm{liter}^{-1}, \mathrm{Y}=0.04+1.53 /(1+\operatorname{EXP}(-0.5(\mathrm{X}-14.6))) ; 200 \mathrm{mg} \cdot \mathrm{liter}^{-1}, \mathrm{Y}$ $=-0.159+4.36 /(1+\operatorname{EXP}(-0.021(X-17))) ; 350 \mathrm{mg} \cdot \operatorname{liter}^{-1}, \mathrm{Y}=0.087+4.4 /(-$ $0.358(X-14.7)))$. The residual mean squares of the fit for the curves were 0.001 , $0.0005,0.15$, and 0.05 , respectively. The ANOVA tests indicated differences among all curves. (B) Tomato seedlings taken from the field after transplanting on day 23 . The numerals refer to the concentration $\left(\mathrm{mg} \cdot \mathrm{liter}^{-1}\right)$ of $\mathrm{N}$ in the nutrient solution provided in the greenhouse.

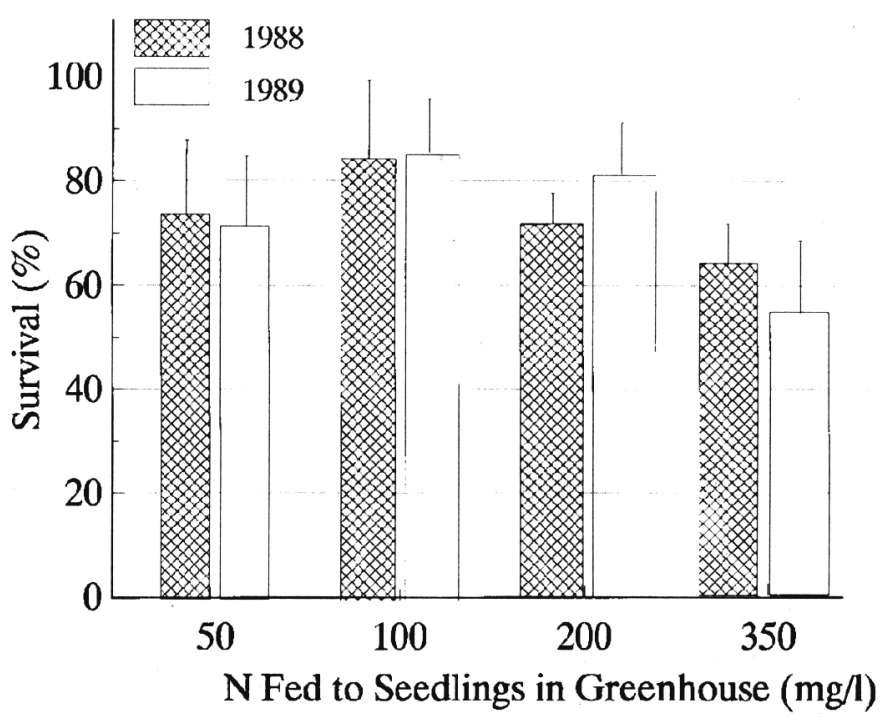

Fig. 4. Survival (\%), 30 days after field transplanting in 1988 and 27 days after transplanting in 1989, of tomato seedlings fed $50,100,200$, or $350 \mathrm{mg} \cdot \operatorname{liter}^{-1} \mathrm{~N}$ in the greenhouse as seedlings. In May 1988, there were two daily occurrences of high winds, 5 and 3 days after transplanting (average speed calculated $>24$ h of $>3.5 \mathrm{~m} / \mathrm{s}$ ), while in May 1989, there were seven occurrences of high winds, on days $1,2,3,12,16,18$, and 22 after transplanting. Tests ( $t$ tests) indicated that the $350 \mathrm{mg} \cdot \mathrm{liter}^{-1} \mathrm{~N}$ treatment was different, $\mathrm{P} \leq 0.05$, from the $200 \mathrm{mg} \cdot \mathrm{liter}^{-1} \mathrm{~N}$ treatment and all the others; there were no other differences.

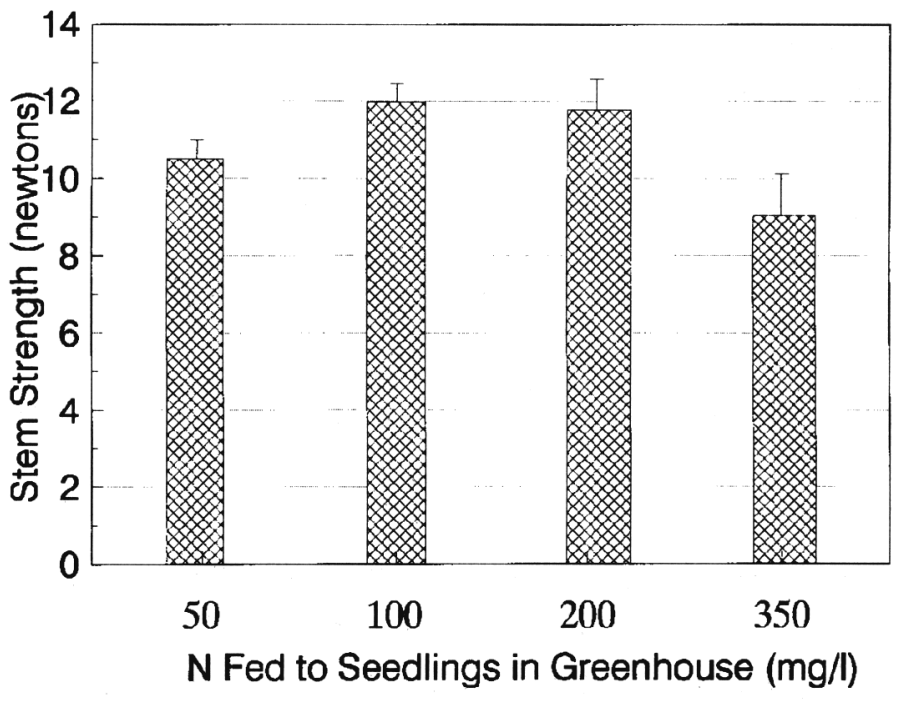

Fig. 5. Stem strength (N) of 6-week-old plants fed 50, 100, 200, or $350 \mathrm{mg} \cdot$ liter $^{-1}$ $\mathrm{N}$ in the greenhouse as seedlings. The means are given with SE from stems of 10 seedlings for each treatment. The LSD test indicated that the $50 \mathrm{mg} \cdot \mathrm{liter}^{-1}$ of $\mathrm{N}$ feeding was not different at $\mathrm{P} \leq 0.05$ from the $100 \mathrm{mg} \cdot \mathrm{liter}^{-1}$ feeding regime, but was different from the other two feeding levels; there were no other differences.

improved by the lower rates, especially under windy weather conditions in fields prone to sandblasting. Nitrogen feeding to tomato seedlings is an important aspect of quality transplant production because of the inverse relationship between growth and hardiness. It is important to have a level of $\mathrm{N}$ application in the greenhouse that gives the maximum hardiness for survival of the crop from sandblasting but at the same time the fastest rate of establishment of the transplants in the field. 


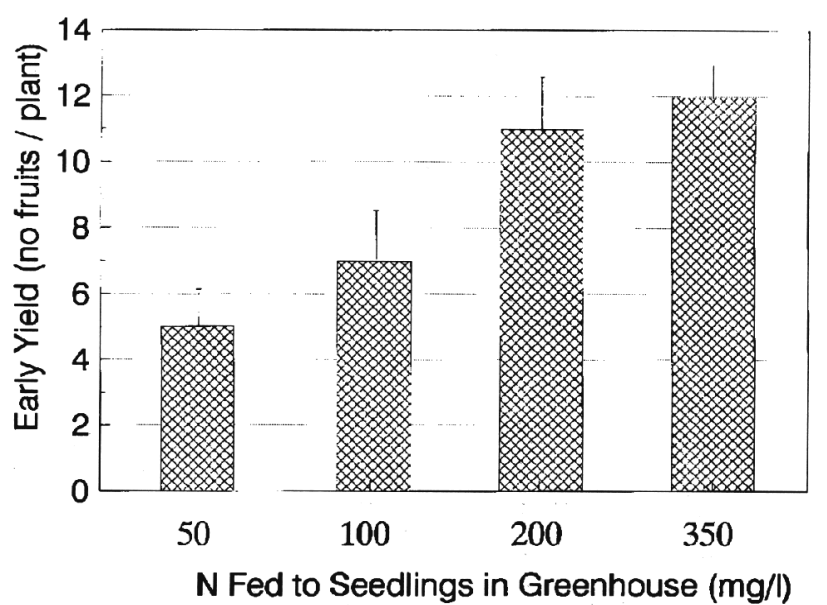

Fig. 6. Early yield on a per plant basis, in 1988, of tomato plants fed 50, 100, 200, or $350 \mathrm{mg} \cdot$ liter $^{-1} \mathrm{~N}$ in the greenhouse as seedlings, combined from the Fox Sandy Loam and the Grandby Sandy Loam soil types. The ANOVA results are given in the text of the results section.

\section{Literature Cited}

Burns, I.G. 1980. Influence of the spatial distribution of nitrate on the uptake of $\mathrm{N}$ by plants: A review and a model for rooting depth. J. Soil Sci. 31:155-173.

Dufault, R.J. 1986. Influence of nutritional conditioning on muskmelon transplant quality and early yield. J. Amer. Hort. Sci. 111:698-703.

Garton, R.W. and I.E. Widders. 1990. Nitrogen and phosphorus preconditioning of small-plug seedling influence processing tomato productivity. HortScience 25:655-657.

Melton, R. and R.J. Dufault. 1991a. Nitrogen, phosphorus, and potassium fertility regimes affect tomato transplant growth. HortScience 26:141142.

Melton, R. and R.J. Dufault. 1991b. Tomato seedling growth, earliness, yield, and quality following pretransplant nutritional conditioning and low temperatures. J. Amer. Soc. HortScience 116:421-425.

Weston, L.A. and B.H. Zandstra. 1989. Transplant age and $\mathrm{N}$ and $\mathrm{P}$ nutrition effects on growth and yield of tomatoes. HortScience 24:8890.

Widders, I.E. 1989. Pretransplant treatments of $\mathrm{N}$ and $\mathrm{P}$ influence growth and elemental accumulation in tomato seedlings. J. Amer. Soc. Hort. Sci. 114:416-420. 